Check for updates

Cite this: RSC Adv., 2021, 11, 7972

Received 14th January 2021

Accepted 11th February 2021

DOI: 10.1039/d1ra00329a

rsc.li/rsc-advances

\section{2,3-Dimethoxy-2,3-dimethyl-1,4-dioxane as a useful precursor to 2,3-dimethylene-1,4-dioxane for [4+2] cycloaddition reaction $\uparrow$}

\author{
Makoto Shimizu, (DD *ab Toshihiro Yamamoto, ${ }^{\mathrm{b}}$ Hiroaki Shindo, ${ }^{\mathrm{b}}$ Isao Mizota (D) ${ }^{\mathrm{b}}$ \\ and Yusong Zhu iD a
}

2,3-Dimethoxy-2,3-dimethyl-1,4-dioxane readily prepared from biacetyl serves as a stable precursor to 2,3-dimethylene-1,4-dioxane which undergoes a [4+2] cycloaddition reaction with dienophiles to give functionalized cyclohexene derivatives. The cycloaddition adducts obtained by the present procedure are transformed into potentially useful intermediates for biologically important materials.

\section{Introduction}

In conjunction with the synthetic study of biologically important 1,2-dihydroxycyclohexanes and their 1,2-hydroxylamine analogues such as alpha-1 adrenoceptor antagonist, ${ }^{1}$ sulfonamide CA inhibitor, ${ }^{2}$ and fliposome (DDS) ${ }^{3}$ (Scheme 1), we needed a simple and reliable method for the synthesis of these particular structures. Regarding the construction of sixmembered carbocycles, the power of the Diels-Alder reaction means it has been recognized as one of the most reliable and straightforward approaches to these molecules, and several functionalized 1,3-dienes have been devised. ${ }^{4}$ Among the dienes explored, 2,3-dialkoxy-1,3-butadienes ${ }^{5}$ have received considerable attention since the cycloaddition products with dienophiles are latent 2-hydroxycyclohexanones which can be transformed into a variety of cyclohexanol derivatives. We have been interested in the synthesis and use of 2,3-dimethylene-1,4dioxane for constructing thiophene derivatives, ${ }^{6}$ which include 3,4-ethylenedioxythiophene (EDOT) commonly used as a starting material for poly(3,4-ethylenedioxythiophene) (PEDOT), one of the most useful electron-conducting polymers. ${ }^{7}$ During these investigations, Diels-Alder cycloaddition using this particular diene intrigued us. A literature search into such diene has revealed that some derivatives are known, but many of them are unstable at room temperature. ${ }^{8}$

In an effort to find a stable precursor to this diene, we screened several compounds, and among the derivatives examined 2,3-dimethoxy-2,3-dimethyl-1,4-dioxane 3 shows a reasonable stability and can work as a good precursor to 2,3-

${ }^{a}$ School of Energy Science and Engineering, Nanjing Tech University, Nanjing 211816, Jiangsu Province, China

${ }^{b}$ Department of Chemistry for Materials, Graduate School of Engineering, Mie University, Tsu, Mie 514-8507, Japan. E-mail: mshimizu@chem.mie-u.ac.jp

$\dagger$ Electronic supplementary information (ESI) available. See DOI: 10.1039/d1ra00329a dimethylene-1,4-dioxane 2 . This paper describes [4+2] cycloaddition reactions using 2,3-dimethoxy-2,3-dimethyl-1,4-dioxane 3 with dienophiles (Scheme 2, eqn (1)) and subsequent transformations of the cycloaddition products.

\section{Results and discussion}

An initial examination was carried out to find good precursors to the diene 2. The investigation involves the use of readily available starting materials to synthesize a relatively large amount of the desired product. Among the derivatives<smiles>O=C(O)[C@H]1CC(O)C(O)C[C@H]1C(=O)NCCCCN1CCN(c2cc(F)ccc2O)CC1</smiles><smiles>NC(=O)C1CC(O)C(O)CC1C(=O)O</smiles>

Sulfonamide CA inhibitor<smiles>O=C(O)[C@H]1C[C@H](O)[C@@H](O)C[C@H]1C(=O)NCCCCN1CCN(c2cc(F)ccc2O)CC1</smiles><smiles>NC(=O)C1C[C@H](O)[C@@H](O)CC1C(=O)O</smiles>

Alpha-1 adrenoceptor antagonist

Sulfonamide CA inhibitor

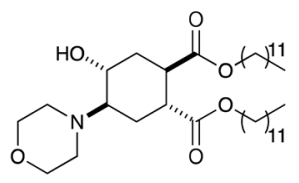

Fliposome (drug delivery system)

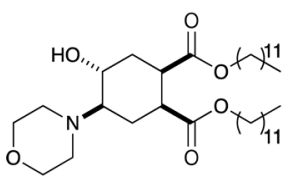

Fliposome (drug delivery system)
Scheme 1 Biologically important materials containing a cyclohexanol moiety. 
<smiles>C=C(O)C(=C)O</smiles><smiles>C=C1OCCOC1=C</smiles><smiles>CO[C@]1(C)OCCOC1(C)C</smiles><smiles>CC(C)(C)C1CC2=C(CC1C(C)(C)C)OCCO2</smiles>
3
(1)

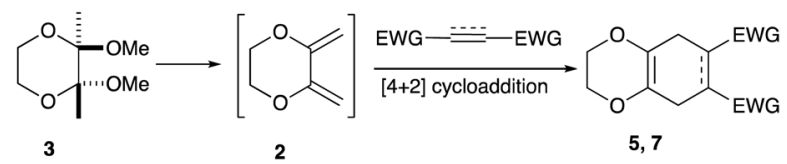

Scheme 2 Particular dienes, a precursor, and adducts

examined 2,3-dimethoxy-2,3-dimethyl-1,4-dioxane 3 show promising results (Scheme 3).

2,3-Dimethoxy-2,3-dimethyl-1,4-dioxane 3 was readily prepared from butane-2,4-dione 4 under camphorsulfonic acidcatalyzed acetalization conditions in $95 \%$ yield (Scheme 3, eqn (1)). Several attempts to convert 2,3-dimethoxy-2,3-dimethyl-1,4dioxane 3 into 2,3-dimethylene-1,4-dioxane 2 under either acidic or basic conditions met with disappointing results, where only a trace amount of the desired diene 2 was obtained (Scheme 3, eqn (2)). However, the treatment of 2,3-dimethoxy2,3-dimethyl-1,4-dioxane 3 with $N$-phenylmaleimide in the presence of a catalytic amount of aluminum chloride under microwave irradiation at $180{ }^{\circ} \mathrm{C}$ produced the $[4+2]$ cycloaddition product $5 \mathrm{a}$ in $24 \%$ yield (Scheme 3 , eqn (3)), indicating that the in situ generation of the diene 2 could be used for the cycloaddition process. We next examined the best cycloaddition reaction conditions using $N$-phenylmaleimide as a dienophile, and Table 1 summarizes the results.

Due to the instability of the intermediary 2,3-dimethylene1,4-dioxane 2, excess amounts of 2,3-dimethoxy-2,3-dimethyl1,4-dioxane 3 were used throughout the present study and the yields were determined on the basis of the dienophile, $N$-phenylmaleimide. The use of 2 equivalents of 2,3-dimethoxy-2,3dimethyl-1,4-dioxane 3 in the presence of $\mathrm{AlCl}_{3}$ increased the product yield up to $51 \%$ (entry 1 ). A better yield was obtained when the reaction was carried out at $200{ }^{\circ} \mathrm{C}$, whereas the yield decreased at $220{ }^{\circ} \mathrm{C}$ (entries 2 and 3). We next examined the

(1)<smiles>CO[C@@]1(C)OCCO[C@@]1(C)OC</smiles>

(3)

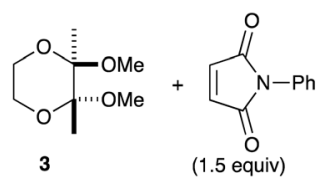

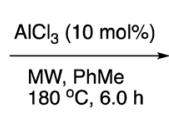

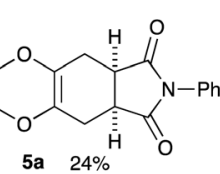

Scheme 3 Preparation of 2,3-dimethoxy-2,3-dimethyl-1,4-dioxane 3 and its reaction.

Table 1 Examination of the reaction conditions

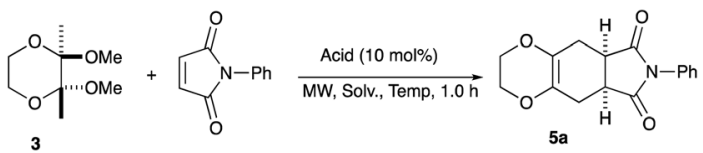

\begin{tabular}{|c|c|c|c|c|c|}
\hline Entry & $\begin{array}{l}\text { 3: } \\
\text { equiv. }\end{array}$ & Solv. & Acid & Temp. $\left({ }^{\circ} \mathrm{C}\right)$ & Yield $^{a}(\%)$ \\
\hline 1 & 2.0 & $\mathrm{PhCH}_{3}$ & $\mathrm{AlCl}_{3}$ & 180 & 51 \\
\hline 2 & 2.0 & $\mathrm{PhCH}_{3}$ & $\mathrm{AlCl}_{3}$ & 200 & 68 \\
\hline 3 & 2.0 & $\mathrm{PhCH}_{3}$ & $\mathrm{AlCl}_{3}$ & 220 & 44 \\
\hline 4 & 3.0 & $\mathrm{PhCH}_{3}$ & $\mathrm{AlCl}_{3}$ & 200 & 73 \\
\hline 5 & 5.0 & $\mathrm{PhCH}_{3}$ & $\mathrm{AlCl}_{3}$ & 200 & 59 \\
\hline 6 & 3.0 & $\mathrm{PhCH}_{3}$ & $\mathrm{Et}_{2} \mathrm{AlCl}$ & 200 & 75 \\
\hline 7 & 3.0 & $\mathrm{PhCH}_{3}$ & $\mathrm{ZrCl}_{4}$ & 200 & 80 \\
\hline 8 & 3.0 & $\mathrm{PhCH}_{3}$ & $\mathrm{ZnCl}_{2}$ & 200 & 32 \\
\hline 9 & 3.0 & $\mathrm{PhCH}_{3}$ & $\mathrm{PTSA} \cdot \mathrm{H}_{2} \mathrm{O}^{b}$ & 200 & 89 \\
\hline 10 & 3.0 & $\mathrm{PhCH}_{3}$ & $\mathrm{CSA}^{c}$ & 200 & 82 \\
\hline 11 & 3.0 & $\mathrm{PhCH}_{3}$ & $\mathrm{AcOH}$ & 200 & 0 \\
\hline 12 & 3.0 & $n$ Hex & $\mathrm{PTSA} \cdot \mathrm{H}_{2} \mathrm{O}$ & 200 & 0 \\
\hline 13 & 3.0 & $\mathrm{DCE}^{d}$ & $\mathrm{PTSA} \cdot \mathrm{H}_{2} \mathrm{O}$ & 200 & 73 \\
\hline 14 & 3.0 & EtCN & $\mathrm{PTSA} \cdot \mathrm{H}_{2} \mathrm{O}$ & 200 & 34 \\
\hline 15 & 3.0 & THF & $\mathrm{PTSA} \cdot \mathrm{H}_{2} \mathrm{O}$ & 200 & 19 \\
\hline
\end{tabular}

${ }^{a}$ Isolated yield. ${ }^{b} p$-Toluenesulfonic acid $\cdot \mathrm{H}_{2} \mathrm{O} .{ }^{c}$ Camphorsulfonic acid. 1,2-Dichloroethane.

amount of 2,3-dimethoxy-2,3-dimethyl-1,4-dioxane 3. The use of 3.0 equivalents of 3 recorded a better yield of the desired product 5a, although a large amount of $\mathbf{3}$ did not improve its formation (entries 4 and 5). Further examination into the use of other Lewis acids revealed that $\mathrm{Et}_{2} \mathrm{AlCl}$ and $\mathrm{ZrCl}_{4}$ could be used with comparable efficiency, although $\mathrm{ZnCl}_{2}$ was less effective (entries 6-8). The use of Brønsted acids recorded better results. Among the Brønsted acids examined the presence of $p$-toluenesulfonic acid $\cdot \mathrm{H}_{2} \mathrm{O}$ recorded the best result, while camphorsulfonic acid could be used (entries 9 and 10). However, simple carboxylic acids (acetic acid) appear to be too weak to promote the 2,3-dimethylene-1,4-dioxane 2 formation (entry 11). The reactions in other solvents were also examined briefly. Although $n$ hexane, EtCN, and THF were not suitable, DCE may be used with a small decrease in the product yield (entries 1215). Thus, the optimized reaction conditions (entry 9) were found and used for further [4+2] cycloaddition reactions with 2,3-dimethoxy-2,3-dimethyl-1,4-dioxane 3. Table 2 summarizes $[4+2]$ cycloaddition reactions using various dienophiles.

As shown in Table 2, among N-substituted maleimides examined the reaction using $N$-phenyl maleimide gave the addition product in the best yield of $89 \%$, while its benzyl and $n$ butyl analogues recorded decreased yields of 76 and $44 \%$, respectively (entries 1-3). However, maleic anhydride could not be used as the dienophile for the present cycloaddition (entry 4). The use of diethyl acetylenedicarboxylate gave the addition product in 58\% yield (entry 5). Regarding the mono-substituted olefins, although MVK did not give the addition product 5f, ethyl acrylate afforded the cycloaddition the adduct $5 \mathrm{~g}$ in $25 \%$ yield (entries 6 and 7). While simple styrene did not give the 
Table 2 [4+2] cycloaddition reaction using various dienophiles

\begin{tabular}{|c|c|c|c|c|c|c|c|}
\hline & & & Dienophile & $\begin{array}{l}\text { PTSA. } \mathrm{H}_{2} \mathrm{O}(10 \mathrm{~mol} \%) \\
\mathrm{MW}, \mathrm{PhCH}_{3}, 200^{\circ} \mathrm{C}, 1.0 \mathrm{~h}\end{array}$ & $\begin{array}{c}\text { Product } \\
5 \mathrm{a}-\mathrm{j}\end{array}$ & & \\
\hline Entry & Dienophile & Product & Yield $^{a}$ & Entry & Dienophile & Product & Yield $^{a}$ \\
\hline 1 & & & $89 \%$ & 6 & & & $0 \%$ \\
\hline 2 & & & $76 \%$ & 7 & & & $25 \%$ \\
\hline 3 & & & $44 \%$ & 8 & & & $0 \%$ \\
\hline 4 & & & $0 \%$ & 9 & & & $17 \%$ \\
\hline 5 & COOEt & & $56 \%$ & 10 & & & $25 \%$ \\
\hline
\end{tabular}

cycloaddition product due to the polystyrene formation, 4- and 2-vinylpyridines gave the desired products in 17 and 25\%, respectively (entries 8-10). These results indicate that the present procedure suffers from the side reaction of polymerization of the intermediate 2,3-dimethylene-1,4-dioxane 2 due to the high reaction temperature necessary for the formation of this particular diene 2 from the precursor 3. Therefore, an excess amount of the diene precursor $\mathbf{3}$ is required for the optimum results and relatively stable dienophiles at high temperatures appear to be applicable. Regarding the reactivity and stability of 2,3-dimethylene-1,4-dioxane derivatives, several substituted derivatives were examined, and Table 3 summarizes the results.

As can be seen from Table 3, the use of other substituted precursor 6a-d did not record better results than that of 2,3dimethoxy-2,3-dimethyl-1,4-dioxane 3 . The benzo derivatives $\mathbf{6 a}$ gave a small amount of the desired product (entry 1). 5,6Dimethoxycarbonyl derivatives $\mathbf{6 b}$, $\mathbf{c}$ may be used, in which the cis-isomer 6c was preferred (entries 2 and 3). Cyclohexane derivative $\mathbf{6 d}$ could be used as a diene precursor for the present cycloadditions, giving the adduct $\mathbf{7 d}$ in good yield (entry 4 ). In the cases of the low yields of the desired products, undesired polymerization of the intermediate diene was a major side reaction, and several attempts (addition of radical scavengers, reactions at lower temperatures, etc.) did not improve the product yields. Regarding the pathways of the present cycloaddition, there exist two representative mechanisms; non-polar and polar ones. ${ }^{9}$ Considering the nature of the diene and

dienophiles used in the present study, the present [4+2] cycloaddition reaction would proceed via a polar mechanism. We next examined the transformation of the Diels-Alder adduct 5a

Table 3 [4+2] cycloaddition reaction using various diene precursors $6 a-d$

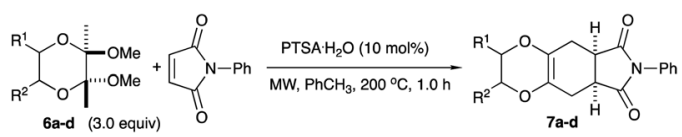

$\begin{array}{lll}\text { Entry Dienophile } & \text { Product } & \text { Yield }^{a}(\%)\end{array}$

1<smiles>CC(C)C1(C)Oc2ccccc2OC1(C)C</smiles><smiles>CO[C@H]1O[C@H](C(C)=O)[C@@](C)(OC)O[C@H]1C(C)=O</smiles>
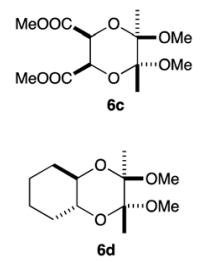

${ }^{a}$ Isolated yield.

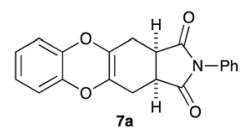<smiles>CCCN1C(=O)[C@H]2CC3=C(C[C@H]2C1=O)O[C@H](C(C)=O)C(C(C)=O)O3</smiles><smiles>CCCCN1C(=O)[C@@H]2CC3=C(C[C@H]2C1=O)O[C@H](C(C)=O)C(C(C)=O)O3</smiles><smiles>O=C1[C@H]2CC3=C(C[C@H]2C(=O)N1Pc1ccccc1)OC1CCCC[C@H]1O3</smiles>

71 
(1)

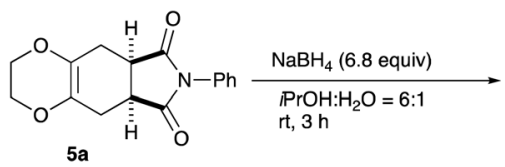<smiles>O=C(Nc1ccccc1)[C@H]1CC2=C(C[C@H]1CO)OCCO2</smiles>

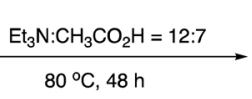<smiles>O=C1OC[C@@H]2CC3=C(C[C@H]12)OCCO3</smiles>

(2)

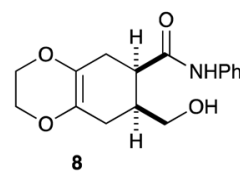
tBuCOCl (1.1 equiv)
$\mathrm{Et}_{3} \mathrm{~N}(1.2$ equiv)
$\mathrm{DMAP}^{\mathrm{O}(0.2 \text { equiv) }}$
$\mathrm{CH}_{2} \mathrm{Cl}_{2}, 0^{\circ} \mathrm{C}$ to $\mathrm{rt}, 9 \mathrm{~h}$

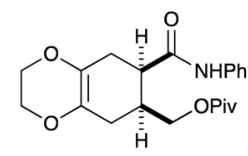
$\overrightarrow{T H F: \mathrm{H}_{2} \mathrm{O}=4: 1, \mathrm{rt}, 30 \mathrm{~min}}$

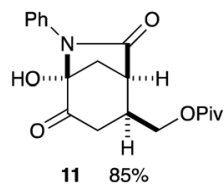
$1080 \%$<smiles>NOC[C@@H]1CC(N2CCOCC2)[C@@H](O)CC1C(=O)Nc1ccccc1</smiles>

Scheme 4 Useful transformations of the Diels-Alder adduct $5 a$.

to useful intermediates to biologically important materials. Scheme 4 summarizes the results.

Regarding the imide moiety, $\mathrm{NaBH}_{4}$ reduction readily opened up the five-membered ring to give the hydroxy amide 8 in $71 \%$ yield. The subsequent lactonization was conducted with $\mathrm{Et}_{3} \mathrm{~N}$ in $\mathrm{AcOH}$ at $80{ }^{\circ} \mathrm{C}$ to give the $\gamma$-lactone 9 in $72 \%$ yield (Scheme 4, eqn (1)). ${ }^{10}$ Removal of the dioxane ring was next examined. Several oxidative transformations were attempted, in which the primary hydroxy group often participated in the oxidation to give many byproducts, and therefore, this hydroxy function was protected as the pivalate 10. Treatment of the alcohol 8 with pivaloyl chloride in the presence of $\mathrm{DMAP} / \mathrm{Et}_{3} \mathrm{~N}$ in $\mathrm{CH}_{2} \mathrm{Cl}_{2}$ at $0{ }^{\circ} \mathrm{C}$ to $\mathrm{rt}$ for $9 \mathrm{~h}$ gave the pivalate 10 in $80 \%$ yield. The pivalate 10 was then treated with NBS in $\mathrm{THF}-\mathrm{H}_{2} \mathrm{O}$ at $\mathrm{rt}$ for 30 min cleanly cleaved the dioxane ring to give the cyclized

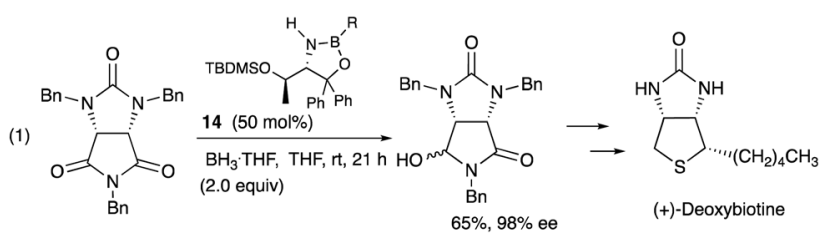<smiles></smiles><smiles>O=C1[C@H]2CC3=C(C[C@H]2[C@H](O)N1c1ccccc1)OCCO3</smiles>

Scheme 5 Desymmetrization reaction using the oxazaborolidine catalyst 14 .
Table 4 Desymmetrization catalyzed by the oxazaborolidine 14
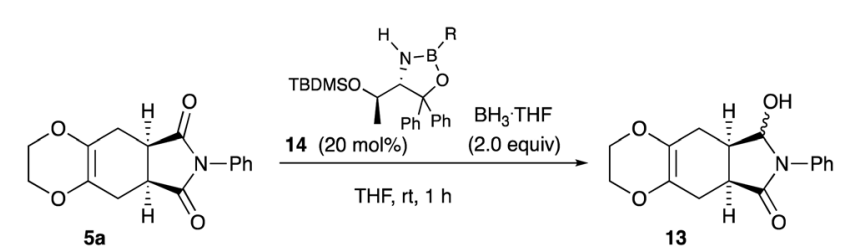

\begin{tabular}{|c|c|c|c|c|c|}
\hline Entry & $\mathrm{R}$ & $\begin{array}{l}\mathrm{BH}_{3} \cdot \mathrm{THF} \\
\text { (equiv.) }\end{array}$ & Solvent & Yield $^{a}(\%)$ & $\mathrm{ee}^{b}(\%)$ \\
\hline 1 & $\mathrm{H}^{c}$ & 2.0 & THF & 58 & 98 \\
\hline 2 & $\mathrm{H}$ & 2.0 & $\mathrm{THF}$ & 51 & 89 \\
\hline 3 & OMe & 2.0 & THF & 61 & 98 \\
\hline 4 & $\mathrm{OMe}^{d}$ & 2.0 & THF & 11 & 77 \\
\hline 5 & $\mathrm{OMe}^{e}$ & 2.0 & $\mathrm{THF}$ & 55 & 93 \\
\hline 6 & OMe & 1.0 & $\mathrm{THF}$ & 11 & 80 \\
\hline 7 & OMe & 2.5 & $\mathrm{THF}$ & 62 & 91 \\
\hline 8 & OEt & 2.5 & $\mathrm{THF}$ & 37 & 81 \\
\hline 9 & OMe & 3.0 & $\mathrm{THF}$ & 45 & 99 \\
\hline 10 & OMe & 2.0 & $\mathrm{PhCH}_{3}$ & 32 & 99 \\
\hline 11 & OMe & 2.0 & $\mathrm{CH}_{2} \mathrm{Cl}_{2}$ & 51 & 99 \\
\hline 12 & OMe & 2.0 & $\mathrm{Et}_{2} \mathrm{O}$ & 55 & 97 \\
\hline 13 & OMe & 2.0 & Dioxane & 52 & 89 \\
\hline 14 & OMe & 2.0 & DME & 55 & 99 \\
\hline
\end{tabular}

${ }^{a}$ Isolated yield. ${ }^{b}$ Determined by HPLC using a chiral stationary column (Daicel IB) after transformation into the ethoxy derivative $\mathbf{1 5}$ (Scheme 6). ${ }^{c}$ Oxazaborolidine $(50 \mathrm{~mol} \%)$ was used. ${ }^{d}$ Reaction was carried out at $0{ }^{\circ} \mathrm{C} .{ }^{e}$ Reaction was carried out for $0.5 \mathrm{~h}$.

bicyclic product $\mathbf{1 1}$ in $85 \%$ yield. Toward the synthesis of important compounds for the drug delivery system (see, Scheme 1), a morpholino moiety was introduced via reductive amination. The lactam 11 was reduced with $\mathrm{NaBH}_{3} \mathrm{CN}$ in the presence of morpholine in EtOH to give the amino alcohol 12 in $52 \%$ yield. ${ }^{11}$ This amino alcohol 12 is a potential intermediate for the synthesis of a series of fliposomes (DDS) (Scheme 4, eqn (2)). We next focussed on the symmetrical features of the DielsAlder adduct 5a.

Desymmetrization $^{\mathbf{1 2}}$ reaction of the Diels-Alder adducts 5a was examined to obtain chiral molecules. Several years ago, we reported the synthesis of deoxybiotine using the reductive desymmetrization reaction of imides as a crucial step (Scheme 5 , eqn (1)). ${ }^{13}$ The same procedure was applied to the present Diels-Alder adducts (Scheme 5, eqn (2)), and Table 4 summarizes the results.

As shown in Table 4, the oxazaborolidine $14(\mathrm{R}=\mathrm{H}$, $50 \mathrm{~mol} \%$ ) used for the synthesis of (+)-deoxybiotine worked well to give the hydroxy lactone $\mathbf{1 3}$ with a high ee of $98 \%$ (entry 1 )<smiles>O=C1[C@H]2CC3=C(C[C@H]2C(O)N1c1ccccc1)OCCO3</smiles>

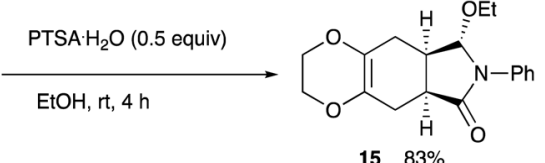

Scheme 6 Transformation of the hydroxy lactam 13 into the ethoxy lactam 15 
which was determined after the transformation into the ethoxy derivative 15 (Scheme 6) ${ }^{14}$ However, decreasing the amount of the catalyst to $20 \mathrm{~mol} \%$ decreased the ee value to $89 \%$ (entry 2). Introducing an alkoxy group onto the boron atom sometimes improves the discrimination ability. Actually, the use of the Bmethoxy derivative $14(\mathrm{R}=\mathrm{OMe}, 20 \mathrm{~mol} \%)$ recorded an excellent ee of $98 \%$ (entry 3). Lowering the reaction temperature did not improve the result (entry 4). A decreased reaction time decreased both the yield and the ee (entry 5). The amount of the reducing reagent $\mathrm{BH}_{3}$. THF was next examined. As you can see, the best result was obtained when the reaction was carried out with 2 equivalents of $\mathrm{BH}_{3} \cdot \mathrm{THF}$ (entries 3, 6, 7, and 9). The use of the B-ethoxy derivative $14(\mathrm{R}=\mathrm{OEt}, 20 \mathrm{~mol} \%)$ did not afford a satisfactory result (entry 8). Regarding the solvents, $\mathrm{CH}_{2} \mathrm{Cl}_{2}$, $\mathrm{Et}_{2} \mathrm{O}$, and DME may be used besides THF (entries 11, 12, and 14). Thus, the Diels-Alder adducts obtained from the present reaction served as good substrates for further functional group transformations.

\section{Conclusions}

In conclusion, 2,3-dimethoxy-2,3-dimethyl-1,4-dioxane 3 readily prepared from biacetyl in good yield works as a convenient precursor to 2,3-dimethylene-1,4-dioxane 2 which can construct functionalized cyclohexene derivatives via a [4+2] cycloaddition reaction with dienophiles. The Diels-Alder adducts obtained by the present procedure are transformed into potentially useful intermediates for biologically important materials. As mentioned in the total synthesis of (+)-biotine and other examples, ${ }^{12,13}$ the desymmetrization of the Diels-Alder adducts also serves as a straightforward method for the preparation of multi-functionalized chiral compounds in a single operation.

\section{Experimental}

\subsection{General aspects}

Reactions under microwave irradiation were carried out using a Biotage Initiator. Analytical techniques: melting points (mp) were determined using a YAMATO MP-21 instrument and are uncorrected. (Solid compounds were not recrystallized.) Infrared spectra were determined on a JASCO FT/IR-460 plus spectrometer. ${ }^{1} \mathrm{H}$ NMR and ${ }^{13} \mathrm{C}$ NMR spectra were recorded with a JEOL ECX-400P, or a JEOL A-500 spectrometer using tetramethylsilane as an internal standard. Mass spectra were recorded on a JEOL MS-700D spectrometer. High-performance liquid chromatography (HPLC) was carried out on a Hitachi L-4200 detector and a Hitachi L-6200 pump using a chiral stationary column (Daicel IB). Materials: toluene $\left(\mathrm{PhCH}_{3}\right)$, dichloroethane (DCE), dichloromethane $\left(\mathrm{CH}_{2} \mathrm{Cl}_{2}\right)$, and $n$ hexane were dried over $\mathrm{CaH}_{2}$, distilled, and stored over molecular sieves 4 A. Propionitrile (EtCN) was distilled from phosphorus pentaoxide and then from calcium hydride, and stored over Molecular Sieves 4A. 1,2-Dimethoxyethane (DME) and 1,4-dioxane were distilled from calcium hydride and then cupper(I) chloride, and stored over sodium. Methanol was distilled from $\mathrm{Mg}$ and stored over molecular sieves $3 \AA$. Ethanol was distilled from EtONa and stored over molecular sieves $4 \AA$ A Isopropyl alcohol was distilled from iPrONa and stored over molecular sieves 4 A. Triethylamine was distilled from $\mathrm{CaH}_{2}$. Tetrahydrofuran (THF) and diethyl ether $\left(\mathrm{Et}_{2} \mathrm{O}\right)$ were purified by the Glass Contour Organic Solvent Purification System of Nikko Hansen \& Co., Ltd. Purification of products was performed by column chromatography on silica gel (Kanto Silica Gel 60N) and/or preparative TLC on silica gel (Merck Kiesel Gel GF254 or Wako Gel B-5F). The staring materials $\mathbf{6 a - d}$ were prepared as reported..$^{15}$

\subsection{Synthesis of 2,3-dimethoxy-2,3-dimethyl-1,4-dioxane 3}

To a solution of ethylene glycol (7.88 g, $127 \mathrm{mmol})$ in $\mathrm{MeOH}$ (63 $\mathrm{mL}$ ) was added 2,3-butanedione (10.0 g, $116 \mathrm{mmol}$ ), trimethyl orthoformate (29.6 g, $279 \mathrm{mmol})$, and camphorsulfonic acid (2.93 g, $12.6 \mathrm{mmol})$ at room temperature under an argon atmosphere. The mixture was stirred at reflux for $24 \mathrm{~h}$. Triethylamine $(1.9 \mathrm{~mL})$ was added to the reaction mixture to quench the reaction. The mixture was diluted with $\mathrm{Et}_{2} \mathrm{O}$ and washed with water, sat. aqueous $\mathrm{NaHCO}_{3}$, and brine, dried over anhydrous $\mathrm{Na}_{2} \mathrm{SO}_{4}$, and filtered. The solvents were evaporated in vacuo and then the residue was purified by chromatography on silica gel ( $n$ Hex : ethyl acetate $=1: 1$, as an eluent) to give 2,3 dimethoxy-2,3-dimethyl-1,4-dioxane 3 (19.4 g, 95\%).

Yield 95\% (19.4 g); a yellow oil; ${ }^{1} \mathrm{H}$ NMR $\left(500 \mathrm{MHz}, \mathrm{CDCl}_{3}\right)$ $\delta 3.95(\mathrm{dd}, J=12.2,19.5 \mathrm{~Hz}, 2 \mathrm{H}), 3.43(\mathrm{dd}, J=12.2,19.5 \mathrm{~Hz}, 2 \mathrm{H})$, $3.31(\mathrm{~s}, 6 \mathrm{H}), 1.29(\mathrm{~s}, 6 \mathrm{H}) ;{ }^{13} \mathrm{C} \mathrm{NMR}\left(126 \mathrm{MHz}, \mathrm{CDCl}_{3}\right) \delta 98.5,58.9$, 48.1, 17.8; IR (neat) 2954, 2831, 1449, 1373, 1308, 1264, 1269, 1141, 1084, 1037, 941, 918, 871, $829 \mathrm{~cm}^{-1}$; HRMS (EI) calcd for $\mathrm{C}_{8} \mathrm{H}_{16} \mathrm{O}_{4}(\mathrm{M})^{+}$176.1049, found 176.1050 .

\subsection{Synthesis of $\left(5 a R^{*}, 8 a S^{*}\right)-7-p h e n y l-2,3,5,5 a, 8 a, 9$ - hexahydro- $6 H$ - $[1,4]$ dioxino[2,3- $f$ isoindole- $6,8(7 H)$-dione $5 a$ (general procedure for the $[4+2]$ cycloaddition)}

To a microwave vial were added $N$-phenylmaleimide $(17.3 \mathrm{mg}$, $0.1 \mathrm{mmol})$, 2,3-dimethoxy-2,3-dimethyl-1,4-dioxane $3(52.9 \mathrm{mg}$, $0.3 \mathrm{mmol}), p$-toluenesulfonic acid $\cdot \mathrm{H}_{2} \mathrm{O}(1.9 \mathrm{mg}, 0.01 \mathrm{mmol})$, and toluene $(1 \mathrm{~mL})$. The vial was sealed with a cap, placed in the microwave cavity, and heated under the following conditions. Absorption level: low, temperature: $200^{\circ} \mathrm{C}$, vial type: $0.5-2.0 \mathrm{~mL}$, pre-stirring: $30 \mathrm{~s}$, reaction time: $1 \mathrm{~h}$, initial power: 0 , dynamic deflector optimization: off. After the reaction, a solution of sat. aqueous $\mathrm{NaHCO}_{3}$ was added to the mixture, which was extracted with EtOAc $(10 \mathrm{~mL} \times 3)$. The combined extracts were washed with sat. aqueous $\mathrm{NaCl}$ and dried over $\mathrm{Na}_{2} \mathrm{SO}_{4}$. After filtration and concentration, the mixture was purified by silica gel column chromatography ( $n$ hexane $:$ ethyl acetate $=2: 1$ ) to give $\left(5 a R^{*}, 8 a S^{*}\right)-7$-phenyl-2,3,5,5a,8a,9-hexahydro- $6 H$-[1,4]dioxino[2,3-f]isoindole-6,8(7H)-dione $5 \mathrm{a}$.

Yield $89 \%$ (25.3 mg); orange solid; $\mathrm{mp}=120-124{ }^{\circ} \mathrm{C} ; R_{\mathrm{f}}=$ 0.40 (nhexane : ethyl acetate $=2: 1) ;{ }^{1} \mathrm{H}$ NMR $(400 \mathrm{MHz}$, $\left.\mathrm{CDCl}_{3}\right): \delta 2.57-2.71(\mathrm{~m}, 4 \mathrm{H}), 3.23-3.30(\mathrm{~m}, 2 \mathrm{H}), 3.99-4.09(\mathrm{~m}$, $4 \mathrm{H}), 7.26-7.29$ (m, 2H), 7.36-7.41 (m, 1H), 7.44-7.49 (m, 2H); ${ }^{13} \mathrm{C}$ NMR $\left(126 \mathrm{MHz}, \mathrm{CDCl}_{3}\right): \delta 25.8,39.5,64.9,126.2,127.7$, 128.5, 129.1, 131.9, 178.3; IR (neat): 2926, 1711, 1598, 1500, 1386, 1229, 1195, 1039, 917, 732, $693 \mathrm{~cm}^{-1}$; HRMS (EI) calcd for $\mathrm{C}_{16} \mathrm{H}_{15} \mathrm{NO}_{4}(\mathrm{M})^{+}$285.1001, found 285.1001. 
$4.4\left(5 a R^{*}, 8 a S^{*}\right)-7-b e n z y l-2,3,5,5 a, 8 a, 9-h e x a h y d r o-6 H-[1,4]$ dioxino $[2,3-f]$ isoindole-6,8(7H)-dione $5 \mathrm{~b}$

Yield 76\% (22.8 mg); orange oil; $R_{\mathrm{f}}=0.50$ ( $n$ hexane : ethyl acetate $=2: 1) ;{ }^{1} \mathrm{H}$ NMR $\left(400 \mathrm{MHz}, \mathrm{CDCl}_{3}\right): \delta 2.47-2.59(\mathrm{~m}, 4 \mathrm{H})$, 3.07-3.12 (m, 2H), 3.75-3.80 (m, 2H), 3.91-3.97 (m, 2H), 4.66 (s, 2H), 7.22-7.35 (m, 5H); ${ }^{13} \mathrm{C} \mathrm{NMR}\left(126 \mathrm{MHz}, \mathrm{CDCl}_{3}\right): \delta 25.9,39.6$, 42.6, 64.8, 127.6, 127.8, 128.4, 128.6, 135.9, 179.0; IR (neat): 2928, 2872, 1700, 1431, 1399, 1346, 1277, 1227, 1173, 1033, 951, $734,702 \mathrm{~cm}^{-1}$; HRMS (EI) calcd for $\mathrm{C}_{10} \mathrm{H}_{10} \mathrm{NO}_{4}\left(\mathrm{M}-\mathrm{C}_{7} \mathrm{H}_{7}\right)^{+}$ 208.0610, found 208.0610.

\section{5 $\left(5 a R^{*}, 8 a S^{*}\right)-7-B u t y l-2,3,5,5 a, 8 a, 9-h e x a h y d r o-6 H-[1,4]$} dioxino $[2,3-f]$ isoindole-6,8 $(7 \mathrm{H})$-dione $5 \mathrm{c}$

Yield 44\% (11.6 mg); orange oil; $R_{\mathrm{f}}=0.50$ (nhexane : ethyl acetate $=2: 1) ;{ }^{1} \mathrm{H} \mathrm{NMR}\left(400 \mathrm{MHz}, \mathrm{CDCl}_{3}\right): \delta 0.92(\mathrm{t}, J=7.3 \mathrm{~Hz}$, $3 \mathrm{H}), 1.25-1.32(\mathrm{~m}, 2 \mathrm{H}), 1.51-1.57(\mathrm{~m}, 2 \mathrm{H}), 2.50-2.59(\mathrm{~m}, 4 \mathrm{H})$, 3.07-3.08 (m, 2H), $3.52(\mathrm{t}, J=7.0 \mathrm{~Hz}, 2 \mathrm{H}), 3.95-4.05(\mathrm{~m}, 4 \mathrm{H})$; ${ }^{13} \mathrm{C}$ NMR (126 MHz, $\left.\mathrm{CDCl}_{3}\right): \delta 13.6,19.9,25.8,25.9,29.7,38.8$, 64.9, 127.7, 179.4; IR (neat): 2933, 2873, 1775, 1700, 1439, 1402, 1356, 1227, 1197, 1113, 1042, 946, $890 \mathrm{~cm}^{-1}$; HRMS (EI) calcd for $\mathrm{C}_{10} \mathrm{H}_{10} \mathrm{NO}_{4}\left(\mathrm{M}-\mathrm{C}_{4} \mathrm{H}_{9}\right)^{+}$208.0610, found 208.0611.

\subsection{Diethyl 2,3,5,8-tetrahydrobenzo $[b][1,4]$ dioxine-6,7- dicarboxylate $5 \mathrm{e}$}

Yield 58\% (16.4 mg); yellow oil; $R_{\mathrm{f}}=0.60$ (nhexane : ethyl acetate $=2: 1) ;{ }^{1} \mathrm{H}$ NMR $\left(400 \mathrm{MHz}, \mathrm{CDCl}_{3}\right): \delta 1.30(\mathrm{t}, J=7.1 \mathrm{~Hz}$, $6 \mathrm{H}), 3.13(\mathrm{~s}, 4 \mathrm{H}), 4.10(\mathrm{~s}, 4 \mathrm{H}), 4.23$ (q, $J=7.2 \mathrm{~Hz}, 4 \mathrm{H}) ;{ }^{13} \mathrm{C}$ NMR $\left(126 \mathrm{MHz} \mathrm{CDCl}_{3}\right): \delta 14.0,29.9,61.3,65.9,125.7,131.7,167.0 ; \mathrm{IR}$ (neat): 2979, 2360, 1720, 1459, 1262, 1214, 1133, 1060, 917, 889, $763 \mathrm{~cm}^{-1}$; HRMS (EI) calcd for $\mathrm{C}_{14} \mathrm{H}_{18} \mathrm{O}_{6}(\mathrm{M})^{+}$282.1103, found 282.1101.

\subsection{Ethyl 2,3,5,6,7,8-hexahydrobenzo $[b][1,4]$ dioxine-6-} carboxylate $5 \mathrm{~g}$

Yield $24 \%$ (5.0 mg); colorless oil; $R_{\mathrm{f}}=0.30$ (nhexane : ethyl acetate $=15: 1) ;{ }^{1} \mathrm{H}$ NMR $\left(400 \mathrm{MHz}, \mathrm{CDCl}_{3}\right): \delta 1.26(\mathrm{t}, J=7.1 \mathrm{~Hz}$, $3 \mathrm{H})$, 1.73-1.80 (m, 1H), 1.98-2.03 (m, 1H), 2.14-2.15 (m, 2H), 2.27-2.39 (m, 1H), 2.36-2.45 (m, 1H), 4.01-4.35 (m, 6H); ${ }^{13} \mathrm{C}$ NMR (126 MHz, $\left.\mathrm{CDCl}_{3}\right): \delta 13.8,22.7,25.6,30.1,38.3,40.0,64.6$, 64.7, 128.1, 128.4, 176.0; IR (neat): 3448, 2977, 2933, 2873, 1731, 1456, 1381, 1348, 1313, 1277, 1131, 1042, 891, $876 \mathrm{~cm}^{-1}$. HRMS (EI) calcd for $\mathrm{C}_{11} \mathrm{H}_{16} \mathrm{O}_{4}{ }^{+} 212.1049$, found 212.1055 .

\section{$4.84-(2,3,5,6,7,8-H e x a h y d r o b e n z o[b][1,4]$ dioxin-6-yl $)$} pyridine $5 \mathbf{i}$

Yield 17\% (3.6 mg); dark orange oil; $R_{\mathrm{f}}=0.20$ (nhexane : ethyl acetate $=4: 1) ;{ }^{1} \mathrm{H}$ NMR $\left(400 \mathrm{MHz}, \mathrm{CDCl}_{3}\right): \delta 1.74-1.97(\mathrm{~m}, 2 \mathrm{H})$, 2.13-2.37 (m, 4H), 2.88-2.93 (m, 1H), 4.04-4.13 (m, 4H), 7.167.17 (m, 2H), 8.52-8.53 (m, 2H); ${ }^{13} \mathrm{C} \mathrm{NMR} \mathrm{(126} \mathrm{MHz,} \mathrm{CDCl}_{3}$ ): $\delta$ 25.7, 29.0, 32.7, 39.5, 64.6, 64.7, 122.3, 128.9, 129.9, 149.9, 154.2, 162.1; IR (neat): 2921, 2871, 1718, 1598, 1415, 1201, 1125, 1002, 908, $870 \mathrm{~cm}^{-1}$; HRMS (EI) calcd for $\mathrm{C}_{8} \mathrm{H}_{11} \mathrm{O}_{2}(\mathrm{M}-$ $\left.\mathrm{C}_{5} \mathrm{H}_{4} \mathrm{~N}\right)^{+}$139.0759, found 139.0761.

\section{$4.92-(2,3,5,6,7,8-H e x a h y d r o b e n z o[b][1,4]$ dioxin-6-yl)} pyridine $5 \mathbf{j}$

Yield $25 \%$ (5.5 mg); dark orange oil; $R_{\mathrm{f}}=0.20$ (nhexane : ethyl acetate $=4: 1) ;{ }^{1} \mathrm{H}$ NMR $\left(400 \mathrm{MHz}, \mathrm{CDCl}_{3}\right): \delta 1.85-2.51(\mathrm{~m}, 6 \mathrm{H})$, 3.04-3.10 (m, 1H), 3.98-4.21 (m, 4H), 7.12-7.14 (m, 1H), 7.19$7.21(\mathrm{~m}, 1 \mathrm{H}), 7.61-7.64(\mathrm{~m}, 1 \mathrm{H}), 8.55-8.56(\mathrm{~m}, 1 \mathrm{H}) ;{ }^{13} \mathrm{C} \mathrm{NMR}$ $\left(126 \mathrm{MHz}, \mathrm{CDCl}_{3}\right): \delta$ 26.0, 28.7, 32.0, 42.4, 64.6, 64.7, 121.2, $121.4,129.3,129.8,136.4,149.2,164.2$; IR (neat): 2923, 2364, 1712, 1590, 1472, 1434, 1275, 1200, 1126, 1028, 885, $868 \mathrm{~cm}^{-1}$; HRMS (EI) calcd for $\mathrm{C}_{8} \mathrm{H}_{11} \mathrm{O}_{2}\left(\mathrm{M}-\mathrm{C}_{5} \mathrm{H}_{4} \mathrm{~N}\right)^{+} 139.0759$, found 139.0761 .

\subsection{0 (3aR*,11aS*)-2-Phenyl-3a,4,11,11a-tetrahydro-1H-} benzo $[5,6][1,4]$ dioxino $[2,3-f]$ isoindole-1,3(2H)-dione $7 \mathrm{a}$

Yield $20 \%$ (6.5 mg); orange solid; $\mathrm{mp}=172-177{ }^{\circ} \mathrm{C} ; R_{\mathrm{f}}=0.20$ ( $n$ hexane : ethyl acetate $=5: 1) ;{ }^{1} \mathrm{H}$ NMR (400 $\mathrm{MHz}, \mathrm{CDCl}_{3}$ ): $\delta$ 2.63-2.72 (m, 4H), 3.33-3.35 (m, 2H), 6.64-6.67 (m, 2H), 6.80$6.86(\mathrm{~m}, 2 \mathrm{H}), 7.30-7.48(\mathrm{~m}, 3 \mathrm{H}) ;{ }^{13} \mathrm{C} \mathrm{NMR}$ (100 MHz, $\mathrm{CDCl}_{3}$ ): $\delta 24.3,38.7,116.1,124.0,126.3,127.6,128.7,129.2$, 131.8, 142.6, 177.7; IR (neat): 2914, 1705, 1598, 1493, 1384, 1262, 1194, 1169, $925,850,747 \mathrm{~cm}^{-1}$; HRMS (EI) calcd for $\mathrm{C}_{14} \mathrm{H}_{10} \mathrm{NO}_{4}\left(\mathrm{M}-\mathrm{C}_{6} \mathrm{H}_{5}\right)^{+}$ 256.0610, found 256.0597 .

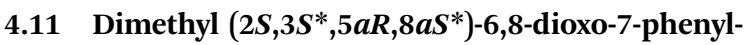
$2,3,5 a, 6,7,8,8 a, 9-o c t a h y d r o-5 H$ - $[1,4]$ dioxino[2,3-f]isoindole2,3-dicarboxylate $7 \mathrm{~b}$

Yield $34 \%$ (13.7 mg); orange oil; $R_{\mathrm{f}}=0.10$ (nhexane : ethyl acetate $=2: 1) ;{ }^{1} \mathrm{H}$ NMR $\left(400 \mathrm{MHz}, \mathrm{CDCl}_{3}\right): \delta 2.65-2.81(\mathrm{~m}, 4 \mathrm{H})$, 3.26-3.32 (m, 2H), 3.66 (s, 3H), $3.81(\mathrm{~s}, 3 \mathrm{H}), 5.01(\mathrm{~s}, 1 \mathrm{H}), 5.03(\mathrm{~s}$, 1H), 7.36-7.38 (m, 5H); ${ }^{13} \mathrm{C} \mathrm{NMR}\left(126 \mathrm{MHz}, \mathrm{CDCl}_{3}\right): \delta 25.2,25.7$, 52.8, 52.9, 72.7, 72.8, 126.5, 127.5, 128.5, 128.9, 132.1, 167.4, 167.9, 177.9, 178.1; IR (neat): 2957, 2856, 1761, 1712, 1498, 1435, 1388, 1217, 1083, 911, 731, $695 \mathrm{~cm}^{-1}$; HRMS (EI) calcd for $\mathrm{C}_{20} \mathrm{H}_{19} \mathrm{NO}_{8}(\mathrm{M})^{+}$401.1111, found 401.1117.

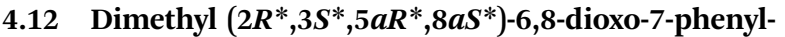
$2,3,5 a, 6,7,8,8 a, 9-o c t a h y d r o-5 H$ - $[1,4]$ dioxino $[2,3-f]$ isoindole2,3-dicarboxylate 7c

Yield 50\% (19.9 mg); orange oil; $R_{\mathrm{f}}=0.10$ (nhexane : ethyl acetate $=2: 1) ;{ }^{1} \mathrm{H}$ NMR $\left(400 \mathrm{MHz}, \mathrm{CDCl}_{3}\right): \delta 2.71-2.88(\mathrm{~m}, 4 \mathrm{H})$, 3.31-3.33 (m, 2H), $3.80(\mathrm{~s}, 6 \mathrm{H}), 4.83(\mathrm{~s}, 2 \mathrm{H}), 7.26-7.48(\mathrm{~m}, 5 \mathrm{H})$; ${ }^{13} \mathrm{C} \mathrm{NMR}\left(126 \mathrm{MHz}, \mathrm{CDCl}_{3}\right): \delta 25.2,39.1,52.8,73.2,125.9,126.1$, 126.7, 127.8, 128.6, 129.1, 166.7, 171.0, 172.2; IR (neat): 2956, 1761, 1710, 1500, 1440, 1388, 1187, 1048, 913, $726 \mathrm{~cm}^{-1}$; HRMS (EI) calcd for $\mathrm{C}_{18} \mathrm{H}_{16} \mathrm{NO}_{6}\left(\mathrm{M}-\mathrm{C}_{2} \mathrm{H}_{3} \mathrm{O}_{2}\right)^{+}$342.0978, found 342.0988 .

\section{$4.13\left(3 a R^{*}, 5 a R^{*}, 9 a R^{*}, 11 a S^{*}\right)-2-$ Phenyl-}

$3 a, 4,5 a, 6,7,8,9,9 a, 11,11 a$-decahydro-1H-benzo[5,6][1,4] dioxino $[2,3-f]$ isoindole-1,3(2H)-dione $7 \mathrm{~d}$

Yield $71 \%$ (24.0 mg); orange oil; $R_{\mathrm{f}}=0.20$ (nhexane : ethyl acetate $=2: 1) ;{ }^{1} \mathrm{H}$ NMR $\left(400 \mathrm{MHz}, \mathrm{CDCl}_{3}\right): \delta 1.30-1.36(\mathrm{~m}, 4 \mathrm{H})$, 1.76 (brs, 2H), 2.08 (brs, 2H), 2.54-2.76 (m, 4H), 3.23-3.30 (m, 2H), 3.41-3.53 (m, 2H), 7.26-7.48 (m, 5H); ${ }^{13} \mathrm{C}$ NMR (126 MHz, $\left.\mathrm{CDCl}_{3}\right): \delta 23.8,23.9,25.4,26.1,29.9,39.4,39.6,60.2,77.0,126.2$, 
127.3, 128.5, 129.1, 132.0, 178.3, 178.4; IR (neat): 2939, 2863, 1704, 1500, 1392, 1228, 1196, 1037, 925, $769 \mathrm{~cm}^{-1}$; HRMS (EI) calcd for $\mathrm{C}_{20} \mathrm{H}_{21} \mathrm{NO}_{4}(\mathrm{M})^{+}$339.1471, found 339.1488.

\subsection{Synthesis of $\left(6 R^{*}, 7 S^{*}\right)-7-($ hydroxymethyl)- $N$-phenyl-} $2,3,5,6,7,8$-hexahydrobenzo $[b][1,4]$ dioxine-6-carboxamide 8

In a $30 \mathrm{~mL}$ two-necked round-bottomed flask equipped with a magnetic stirring bar, a rubber septum, and an argon balloon was placed $\mathrm{NaBH}_{4}(25.7 \mathrm{mg}, 0.68 \mathrm{mmol})$. To it was added a solution of $\left(5 a R^{*}, 8 a S^{*}\right)-7-$ phenyl-2,3,5,5a,8a,9-hexahydro- $6 H$ $[1,4]$ dioxino[2,3-f]isoindole-6,8(7H)-dione $\quad 5 a \quad(28.5 \mathrm{mg} \quad 0.10$ $\mathrm{mmol})$ in iso- $\mathrm{PrOH}(1.8 \mathrm{~mL})-\mathrm{H}_{2} \mathrm{O}(0.3 \mathrm{~mL})$ at $\mathrm{rt}$, and the mixture was stirred at $\mathrm{rt}$ for $3 \mathrm{~h}$. The reaction was quenched with sat. aqueous $\mathrm{NaHCO}_{3}$, and the whole mixture was extracted with $\mathrm{CH}_{2} \mathrm{Cl}_{2}(30 \mathrm{~mL} \times 3)$. The combined extracts were washed with brine $(15 \mathrm{~mL})$, dried $\left(\mathrm{Na}_{2} \mathrm{SO}_{4}\right)$, and concentrated in vacuo. The crude product was purified by silica gel column chromatography (dichloromethane : isopropyl alcohol $=20: 1$ ) to give the title compound.

Yield 71\% (20.5 mg); yellow solid; $\mathrm{mp}=258-262{ }^{\circ} \mathrm{C} ; R_{\mathrm{f}}=$ 0.30 (nhexane : ethyl acetate $=1: 1) ;{ }^{1} \mathrm{H}$ NMR $(400 \mathrm{MHz}$, $\left.\mathrm{CDCl}_{3}\right): \delta 2.05-2.33(\mathrm{~m}, 5 \mathrm{H}), 2.82-2.86(\mathrm{~m}, 1 \mathrm{H}), 3.27-3.44(\mathrm{~m}$, $2 \mathrm{H}), 3.92-4.04(\mathrm{~m}, 4 \mathrm{H}), 4.53(\mathrm{t}, J=5.2 \mathrm{~Hz}, 1 \mathrm{H}), 7.00-7.03(\mathrm{~m}$, 1H), 7.27-7.30 (m, 2H), 7.58-7.59 (m, 2H); ${ }^{13} \mathrm{C}$ NMR (100 MHz, DMSO-d 6 ): $\delta 25.3,27.2,38.2,41.7,59.4,64.0,119.1,123.0,127.5$, 127.7, 128.6, 139.3, 171.6; IR (neat): 3308, 2963, 2933, 1718, 1652, 1598, 1525, 1442, 1331, 1204, 1047, 983, $856 \mathrm{~cm}^{-1}$; HRMS (EI) calcd for $\mathrm{C}_{16} \mathrm{H}_{19} \mathrm{NO}_{4}(\mathrm{M})^{+}$289.1314, found 289. 1312.

\subsection{Synthesis of $\left(5 a R^{*}, 8 a S^{*}\right)-2,3,5,8,8 a, 9-h e x a h y d r o-[1,4]$ dioxino[2,3-f]isobenzofuran-6(5aH)-one 9}

In a $30 \mathrm{~mL}$ two-necked round-bottomed flask equipped with a magnetic stirring bar, a rubber septum, and an argon balloon was placed $\left(6 R^{*}, 7 S^{*}\right)$-7-(hydroxymethyl)- $N$-phenyl-2,3,5,6,7,8hexahydrobenzo[$[b][1,4]$ dioxine-6-carboxamide 8 (42.2 $\mathrm{mg}, 0.15$ $\mathrm{mmol})$. To it was added triethylamine $(2.4 \mathrm{~mL})$ and acetic acid $(1.4 \mathrm{~mL})$ at $\mathrm{rt}$, and the mixture was stirred at $80{ }^{\circ} \mathrm{C}$ for $48 \mathrm{~h}$. The reaction was cooled to $0{ }^{\circ} \mathrm{C}$ and quenched with sat. aqueous $\mathrm{NaHCO}_{3}$. The whole mixture was extracted with $\mathrm{CH}_{2} \mathrm{Cl}_{2}(30 \mathrm{~mL}$ $\times 3)$. The combined extracts were washed with brine $(15 \mathrm{~mL})$, dried $\left(\mathrm{Na}_{2} \mathrm{SO}_{4}\right)$, and concentrated in vacuo. The crude product was purified by silica gel column chromatography (nhexane : ethyl acetate $=1: 1)$ to give the title compound.

Yield $72 \%$ (20.6 mg); colorless oil; $R_{\mathrm{f}}=0.70$ (nhexane : ethyl acetate $=1: 1) ;{ }^{1} \mathrm{H}$ NMR $\left(400 \mathrm{MHz}, \mathrm{CDCl}_{3}\right): \delta 2.09-2.83(\mathrm{~m}, 6 \mathrm{H})$, 4.00-4.09 (m, 5H), 4.26-4.30 (m, $1 \mathrm{H}) ;{ }^{13} \mathrm{C}$ NMR $(100 \mathrm{MHz}$, $\left.\mathrm{CDCl}_{3}\right): \delta 23.2,26.8,33.1,38.1,64.6,72.0,127.1,127.6,177.8$; IR (neat): 2975, 2915, 2878, 1773, 1716, 1451, 1375, 1276, 1208, 1043, 971, $890 \mathrm{~cm}^{-1}$; HRMS (EI) calcd for $\mathrm{C}_{10} \mathrm{H}_{12} \mathrm{O}_{4}(\mathrm{M})^{+}$ 196.0736, found 196. 0743.

4.16 Synthesis of $\left(\left(6 S^{*}, 7 R^{*}\right)-7-(\right.$ phenylcarbamoyl)-2,3,5,6,7,8hexahydrobenzo $[b][1,4]$ dioxin-6-yl)methyl pivalate 10

In a $100 \mathrm{~mL}$ two-necked round-bottomed flask equipped with a magnetic stirring bar, a rubber septum, and an argon balloon was placed $\left(6 R^{*}, 7 S^{*}\right)-7-($ hydroxymethyl)- $N$-phenyl-2,3,5,6,7,8- hexahydrobenzo $[b][1,4]$ dioxine-6-carboxamide 8 (867.9 $\mathrm{mg}, 3.0$ mmol). To it was added triethylamine $(0.50 \mathrm{~mL}, 3.6 \mathrm{mmol})$, DMAP (73.3 mg, $0.60 \mathrm{mmol})$, and dichloromethane $(20 \mathrm{~mL})$ at rt. The mixture was cooled to $0{ }^{\circ} \mathrm{C}$ and to it was slowly added pivaloyl chloride $(0.40 \mathrm{~mL}, 3.3 \mathrm{mmol})$. The mixture was allowed to stand at rt for $9 \mathrm{~h}$. The reaction was quenched with $\mathrm{HCl}(2 \mathrm{M}$, $20 \mathrm{~mL})$. The whole mixture was extracted with $\mathrm{CH}_{2} \mathrm{Cl}_{2}(20 \mathrm{~mL} \times$ $3)$. The combined extracts were washed with brine $(15 \mathrm{~mL})$, dried $\left(\mathrm{Na}_{2} \mathrm{SO}_{4}\right)$, and concentrated in vacuo. The crude product was purified by silica gel column chromatography (nhexane : ethyl acetate $=2: 1$ ) to give the title compound.

Yield $80 \%$ (901.3 mg); yellow solid; $\mathrm{mp}=154-162{ }^{\circ} \mathrm{C} ; R_{\mathrm{f}}=$ 0.40 (nhexane : ethyl acetate $=2: 1) ;{ }^{1} \mathrm{H}$ NMR $(400 \mathrm{MHz}$, $\left.\mathrm{CDCl}_{3}\right): \delta 1.19(\mathrm{~s}, 1 \mathrm{H}), 2.17-2.23(\mathrm{~m}, 1 \mathrm{H}), 2.31-2.36(\mathrm{~m}, 1 \mathrm{H})$, 2.41-2.54 (m, 3H), 2.84-2.89 (m, 1H), 4.08-4.13 (m, 5H), 4.26$4.31(\mathrm{~m}, 1 \mathrm{H}), 7.00-7.13(\mathrm{~m}, 1 \mathrm{H}), 7.30-7.34(\mathrm{~m}, 2 \mathrm{H}), 7.50-7.57$ $(\mathrm{m}, 2 \mathrm{H}), 7.85(\mathrm{~s}, 1 \mathrm{H}) ;{ }^{13} \mathrm{C}$ NMR $\left(100 \mathrm{MHz}, \mathrm{CDCl}_{3}\right): \delta$ 26.7, 27.1, 27.6, 34.9, 38.8, 42.8, 64.6, 64.7, 64.7, 120.0, 124.3, 127.9, 128.4, 128.9, 137.8, 137.8, 170.2, 178.7; IR (neat): 3319, 2972, 2928, 2873, 1720, 1664, 1600, 1540, 1442, 1283, 1199, 1160, 1041, 982, $887 \mathrm{~cm}^{-1}$; HRMS (EI) calcd for $\mathrm{C}_{21} \mathrm{H}_{27} \mathrm{NO}_{5}(\mathrm{M})^{+} 373.1889$, found 373.1876 .

\subsection{Synthesis of $\left[\left(1 R^{*}, 2 S^{*}, 5 R^{*}\right)-5\right.$-hydroxy-4,7-dioxo-6- phenyl-6-azabicyclo[3.2.1] octan-2-yl]methyl pivalate 11}

In a $30 \mathrm{~mL}$ two-necked round-bottomed flask equipped with a magnetic stirring bar, a rubber septum, and an argon balloon was placed $\left[\left(6 S^{*}, 7 R^{*}\right)-7-(\right.$ phenylcarbamoyl)-2,3,5,6,7,8-hexahydrobenzo $[b][1,4]$ dioxin-6-yl]methyl pivalate $(75.0 \mathrm{mg}, \quad 0.20$ $\mathrm{mmol})$. To it was added THF $(8.0 \mathrm{~mL})$, NBS $(35.6 \mathrm{mg}, 0.20$ $\mathrm{mmol})$, and $\mathrm{H}_{2} \mathrm{O}(2.0 \mathrm{~mL})$ successively at $\mathrm{rt}$. The mixture was stirred at $\mathrm{rt}$ for $30 \mathrm{~min}$. The reaction was quenched with sat. aqueous $\mathrm{NaHSO}_{3}$. The whole mixture was extracted with $\mathrm{Et}_{2} \mathrm{O}$ $(10 \mathrm{~mL} \times 3)$. The combined extracts were washed with brine $(15$ $\mathrm{mL})$, dried $\left(\mathrm{Na}_{2} \mathrm{SO}_{4}\right)$, and concentrated in vacuo. The crude product was purified on silica gel TLC ( $n$ hexane $:$ ethyl acetate $=$ $1: 1)$ to give the title compound.

Yield 85\% (58.6 mg); yellow powder; $\mathrm{mp}=62-64{ }^{\circ} \mathrm{C} ; R_{\mathrm{f}}=$ 0.70 (nhexane : ethyl acetate $=1: 1) ;{ }^{1} \mathrm{H}$ NMR $(400 \mathrm{MHz}$, $\left.\mathrm{CDCl}_{3}\right): \delta 1.24(\mathrm{~s}, 9 \mathrm{H}), 2.04-2.12(\mathrm{~m}, 1 \mathrm{H}), 2.48-2.55(\mathrm{~m}, 1 \mathrm{H})$, 2.59-2.68 (m, 1H), 2.77-2.81 (m, 1H), 2.88-2.94 (m, 1H), 3.03$3.04(\mathrm{~m}, 1 \mathrm{H}), 4.09-4.17(\mathrm{~m}, 1 \mathrm{H}), 4.25-4.29(\mathrm{~m}, 1 \mathrm{H}), 4.41(\mathrm{~s}, 1 \mathrm{H})$, 7.08-7.14 (m, 2H), 7.24-7.28 (m, 1H) 7.35-7.38 (m, 2H); ${ }^{13} \mathrm{C}$ NMR (100 MHz, $\left.\mathrm{CDCl}_{3}\right): \delta 27.1,37.1,38.6,38.8,40.7,42.5,64.8$, 90.5, 124.9, 127.2, 127.2, 129.1, 129.1, 133.5, 171.3, 178.0, 204.8; IR (neat): 3404, 2973, 2908, 2875, 1719, 1598, 1542, 1501, 1367, 1285, 1159, $1035 \mathrm{~cm}^{-1}$;. HRMS (EI) calcd for $\mathrm{C}_{19} \mathrm{H}_{23} \mathrm{O}_{5}(\mathrm{M})^{+}$ 345.1576 , found 345.1572 .

\subsection{Synthesis of $\left[\left(1 S^{*}, 2 R^{*}, 4 R^{*}, 5 R^{*}\right)-4\right.$-hydroxy-5- morpholino-2-(phenylcarbamoyl)cyclohexyl]methyl pivalate 12}

In a $30 \mathrm{~mL}$ two-necked round-bottomed flask equipped with a magnetic stirring bar, a rubber septum, and an argon balloon was placed $\left[\left(1 R^{*}, 2 S^{*}, 5 R^{*}\right)\right.$-5-hydroxy-4,7-dioxo-6-phenyl-6azabicyclo[3.2.1] octan-2-yl]methyl pivalate $11(34.5 \mathrm{mg}, 0.10$ 
$\mathrm{mmol})$. To it was added EtOH $(4.0 \mathrm{~mL})$, morpholine $(8.7 \mu \mathrm{L}, 0.10$ $\mathrm{mmol})$, and $\mathrm{NaBH}_{3} \mathrm{CN}(7.5 \mathrm{mg}, 0.12 \mathrm{mmol})$ successively at rt. To the mixture was added $\mathrm{AcOH}$ to reach $\mathrm{pH}$ 6.0, and it was stirred at $\mathrm{rt}$ for $24 \mathrm{~h}$. The reaction was quenched with sat. aqueous $\mathrm{NaHCO}_{3}$. The whole mixture was extracted with $\mathrm{CH}_{2} \mathrm{Cl}_{2}(10 \mathrm{~mL}$ $\times 3)$. The combined extracts were washed with brine $(15 \mathrm{~mL})$, dried $\left(\mathrm{Na}_{2} \mathrm{SO}_{4}\right)$, and concentrated in vacuo. The crude product was purified by silica gel column chromatography (dichloromethane : methanol = $10: 1$ ) to give the title compound.

Yield 52\% (21.7 mg); colorless oil; $R_{\mathrm{f}}=0.30$ (dichloromethane : methanol = $10: 1) ;{ }^{1} \mathrm{H}$ NMR (400 $\left.\mathrm{MHz}, \mathrm{CDCl}_{3}\right)$ : $\delta$ 1.09, (s, 9H)1.53-1.57 (m, 1H), 1.74-1.84 (m, 1H), 2.01-2.04 $(\mathrm{m}, 1 \mathrm{H}), 2.22-2.25(\mathrm{~m}, 1 \mathrm{H}), 2.31-2.35(\mathrm{~m}, 1 \mathrm{H}), 2.46-2.47(\mathrm{~m}, 1 \mathrm{H})$ 2.52-2.54 (m, 1H), 2.57-2.74 (m, 4H), 3.71-3.74 (m, 4H), 3.75$3.76(\mathrm{~m}, 1 \mathrm{H}) 4.05(\mathrm{~s}, 1 \mathrm{H})$ 4.29-4.34 (m, 1H), 4.43-4.48 (m, 1H), 7.07-7.10 (m, 1H), 7.28-7.32 (m, 2H), 7.57-7.59 (m, 2H), $7.83(\mathrm{~s}$, $1 \mathrm{H}) ;{ }^{13} \mathrm{C} \mathrm{NMR}\left(100 \mathrm{MHz}, \mathrm{CDCl}_{3}\right): \delta 21.0,27.0,31.7,34.1,38.6$, 45.6, 50.2, 64.5, 64.5, 67.2, 119.8, 124.2, 128.9, 138.0, 171.0, 179.1; IR (neat): 3310, 2961, 1722, 1600, 1544, 1500, 1442, 1286, $1161,1119,755,517,504 \mathrm{~cm}^{-1}$; HRMS (EI) calcd for $\mathrm{C}_{23} \mathrm{H}_{34} \mathrm{~N}_{2} \mathrm{O}_{5}$ $(\mathrm{M})^{+} 418.2468$, found 418.2477 .

\subsection{Synthesis of $(5 a S, 8 a R)-8$-hydroxy-7-phenyl- $2,3,5,5 a, 7,8,8 a, 9-o c t a h y d r o-6 H-[1,4]$ dioxino $[2,3-f]$ isoindol-6- one 13}

In a $30 \mathrm{~mL}$ two-necked round-bottomed flask equipped with a magnetic stirring bar, a rubber septum, and an argon balloon was placed (2S,3R)-2-amino-3-(tert-butyldimethylsilyloxy)-1,1diphenylbutan-1-ol ${ }^{16}(7.4 \mathrm{mg}, 0.02 \mathrm{mmol})$. To it was added THF $(1.0 \mathrm{~mL})$ and trimethyl borate $(1.0 \mathrm{M}, 0.02 \mathrm{~mL}, 0.02 \mathrm{mmol})$, and the mixture was stirred at $\mathrm{rt}$ for $1 \mathrm{~h}$. To the mixture were slowly added solutions of $\left(5 a R^{*}, 8 a S^{*}\right)$-7-phenyl-2,3,5,5a,8a,9-hexahydro-6H-[1,4]dioxino[2,3-f]isoindole-6,8(7H)-dione 5a $(28.5 \mathrm{mg}$ $0.1 \mathrm{mmol})$ in THF $(2 \mathrm{~mL})$ and $\mathrm{BH}_{3} \cdot \mathrm{THF}(1.0 \mathrm{M}, 0.20 \mathrm{~mL}, 0.20$ $\mathrm{mmol})$. After stirring at $\mathrm{rt}$ for $1 \mathrm{~h}$, the reaction was quenched with sat. aqueous $\mathrm{NaHCO}_{3}$. The whole mixture was extracted with AcOEt $(10 \mathrm{~mL} \times 3)$. The combined extracts were washed with brine $(15 \mathrm{~mL})$, dried $\left(\mathrm{Na}_{2} \mathrm{SO}_{4}\right)$, and concentrated in vacuo. The crude product was purified on silica gel TLC (nhexane : ethyl acetate $=2: 1$ ) to give the title compound.

Yield $61 \%$ (17.5 mg); colorless oil; $R_{\mathrm{f}}=0.10$ (nhexane : ethyl acetate $=1: 1) ;[\alpha]_{\mathrm{D}}^{14}-42.3\left(c 0.012, \mathrm{CHCl}_{3}\right) ;{ }^{1} \mathrm{H} \mathrm{NMR}(400 \mathrm{MHz}$, $\left.\mathrm{CDCl}_{3}\right): \delta 2.30-2.65(\mathrm{~m}, 4 \mathrm{H}), 2.76-2.90(\mathrm{~m}, 3 \mathrm{H}), 4.02-4.14(\mathrm{~m}$, $4 \mathrm{H}), 5.55-5.57(\mathrm{~m}, 1 \mathrm{H}), 7.20-7.54(\mathrm{~m}, 5 \mathrm{H}) ;{ }^{13} \mathrm{C}$ NMR $(100 \mathrm{MHz}$, $\left.\mathrm{CDCl}_{3}\right): \delta 22.9,26.1,37.9,38.6,64.6,64.7,88.5,122.5,126.0$, 126.6, 128.3, 129.2, 137.7, 174.8; IR (neat): 3425, 2920, 1682, 1497, 1404, 1278, 1207, 1128, 1039, 890, $758 \mathrm{~cm}^{-1}$; HRMS (EI) calcd for $\mathrm{C}_{16} \mathrm{H}_{16} \mathrm{NO}_{3}{ }^{+}(\mathrm{M}-\mathrm{HO})^{+} 270.1130$, found 270.1142 .

\subsection{Determination of the enantiomeric purity of the reduction product via the ethoxy derivative 15}

In a $30 \mathrm{~mL}$ two-necked round-bottomed flask equipped with a magnetic stirring bar, a rubber septum, and an argon balloon was placed $(5 a S, 8 a R)$-8-hydroxy-7-phenyl-2,3,5,5a,7,8,8a,9-octahydro- $6 H$-[1,4]dioxino[2,3-f]isoindol-6-one 13 (8.1 mg, 0.028 $\mathrm{mmol})$. To it was added PTSA $\cdot \mathrm{H}_{2} \mathrm{O}(2.7 \mathrm{mg}, 0.014 \mathrm{mmol})$ and
EtOH $(4.0 \mathrm{~mL})$, and the mixture was stirred at rt for $4 \mathrm{~h}$. The reaction was quenched with sat. aqueous $\mathrm{NaHCO}_{3}$. The whole mixture was extracted with $\mathrm{CH}_{2} \mathrm{Cl}_{2}(5 \mathrm{~mL} \times 3)$. The combined extracts were washed with brine $(15 \mathrm{~mL})$, dried $\left(\mathrm{Na}_{2} \mathrm{SO}_{4}\right)$, and concentrated in vacuo. The crude product was purified on silica gel TLC (nhexane : ethyl acetate $=1: 1)$ to give $(5 a S, 8 S, 8 a R)$-8ethoxy-7-phenyl-2,3,5,5a,7,8,8a,9-octahydro-6H-[1,4]dioxino [2,3-f]isoindol-6-one 15.

Yield 83\% (7.4 mg); colorless oil; $R_{\mathrm{f}}=0.50$ ( $n$ hexane : ethyl acetate $=1: 1) ;[\alpha]_{\mathrm{D}}^{25}-46.8\left(c 0.089, \mathrm{CHCl}_{3}\right) ;{ }^{1} \mathrm{H} \mathrm{NMR}(400 \mathrm{MHz}$, $\left.\mathrm{CDCl}_{3}\right): \delta 1.18(\mathrm{dd}, J=6.7,7.3 \mathrm{~Hz}, 3 \mathrm{H}), 1.95-2.05(\mathrm{~m}, 1 \mathrm{H}), 2.28-$ 2.45 (m, 2H), 2.65-2.76 (m, 2H), 3.19-3.22 (m, 1H), 3.49-3.53 (m, 2H), 3.95-4.12 (m, 5H), 4.88 (s, 1H), 7.16-7.19 (m, 1H), 7.33$7.36(\mathrm{~m}, 2 \mathrm{H}), 7.47-7.49(\mathrm{~m}, 2 \mathrm{H}) ;{ }^{13} \mathrm{C} \mathrm{NMR}$ (126 $\left.\mathrm{MHz}, \mathrm{CDCl}_{3}\right)$ : $\delta 15.3,22.8,26.2,35.9,38.0,63.9,64.6,94.6,122.6,125.7,126.5$, 128.5, 128.9, 138.7, 174.8; IR (neat): 2974, 2911, 1714, 1598, 1497, 1395, 1280, 1200, 1071, 920, 890, $859 \mathrm{~cm}^{-1}$; HRMS (EI) calcd for $\mathrm{C}_{16} \mathrm{H}_{16} \mathrm{NO}_{4}\left(\mathrm{M}-\mathrm{C}_{2} \mathrm{H}_{5}\right)^{+} 286.1079$, found 286.1071.

The enantiomeric purity of the above ethoxide 15 was determined by HPLC using a chiral stationary column (Daicel IB). Flow rate $1.0 \mathrm{~mL} \min ^{-1}$, $n$ hexane $: \mathrm{iPrOH}=9: 1$, detection at $254 \mathrm{~nm}$, set temperature $35^{\circ} \mathrm{C}$.

\section{Conflicts of interest}

There are no conflicts to declare.

\section{Acknowledgements}

This work was supported by Grants-in-Aid for Scientific Research (B) and on Innovative Areas "Organic Synthesis Based on Reaction Integration. Development of New Methods and Creation of New Substances" from JSPS and MEXT.

\section{Notes and references}

1 (a) P. K. S. Savithru, P. Gupta, V. Palle, M. S. Rao, R. S. Kombu, K. Rauthan, and V. K. Ramanathan, WO 2007/039809 A1, 2007; (b) D. B. Bylund, in Encyclopedia of Biological Chemistry, ed. W. J. Lennarz and M. D. Lane, Elsevier Inc., Amsterdam, 2nd edn, 2013, pp. 57-60.

2 A. Yıldırım, U. Atmaca, A. Keskin, M. Topal, M. Çelik, I. Gülçin and C. T. Supuran, Bioorg. Med. Chem., 2015, 23, 2598-2605.

3 (a) N. M. Samoshina, X. Liu, B. Brazdova, A. H. Franz, V. V. Samoshin and X. Guo, Pharmaceutics, 2011, 3, 379405; (b) X. Liu, Y. Zheng, N. M. Samoshina, A. H. Franz, X. Guo and V. V. Samoshin, J. Liposome Res., 2012, 22, 319328; (c) J. Lou, X. Zhang and M. D. Best, Chem.-Eur. J., 2019, 25, 20-25.

4 For reviews, see: (a) U. Pindur, G. Lutz and C. Otto, Chem. Rev., 1999, 93, 741-761; (b) A. Kumar, Chem. Rev., 2001, 101, 1-20; (c) S. Reymond and J. Cossy, Chem. Rev., 2008, 108, 5359-5406; (d) P. Wessig and G. Müller, Chem. Rev., 2008, 108, 2051-2063; (e) M. Juhl and D. Tanner, Chem. Soc. Rev., 2009, 38, 2983-2992; (f) V. Nair, R. S. Menon, 
A. T. Biju and K. G. Abhilash, Chem. Soc. Rev., 2012, 41, 10501059.

5 For 2,3-dialkoxy-1,3-butadienes, see: (a) R. K. Summerbell and G. J. Lestina, J. Am. Chem. Soc., 1957, 79, 3878-3884; (b) D. R. Anderson and T. H. Koch, J. Org. Chem., 1978, 43, 2726-2728; (c) H.-D. Scharf, H. Plum, J. Fleischhauer and W. Schleker, Chem. Ber., 1979, 112, 862-882; (d) E. McDonald, A. Suksamrarn and R. D. Wylie, J. Chem. Soc., Perkin Trans. 1, 1979, 1893-1900; (e) N. Ruiz, M. D. Pujol, G. Guillaumet and G. Coudert, Tetrahedron Lett., 1992, 33, 2965-2968; (f) G. Torres-García and J. Mattay, Tetrahedron, 1996, 52, 5421-5426; $(g)$ F. von Kieseritzky, F. Allared, E. Dahlstedt and J. Hellberg, Tetrahedron Lett., 2004, 45, 6049-6050; (h) Y. Kasano, A. Okada, D. Hiratsuka, Y. Oderaotoshi, S. Minakata and M. Komatsu, Tetrahedron, 2006, 62, 537-542; (i) B. J. Compton, D. S. Larsen, L. Larsen and R. T. Weavers, Tetrahedron Lett., 2008, 49, 219-221; (j) B. Linclau, P. J. Clarke and M. E. Light, Tetrahedron Lett., 2009, 50, 7144-7147.

6 I. Hachiya, T. Yamamoto, T. Inagaki, T. Matsumoto, A. Takahashi, I. Mizota and M. Shimizu, Heterocycles, 2014, 88, 607-612.

7 For a review, see: L. Groenendaal, F. Jonas, D. Freitag, H. Pielartzik and J. R. Reynolds, Adv. Mater., 2000, 12, 481494 and references therein.

8 Regarding 2,3-dimethylene-1,4-dioxane 2, it was reported that this particular diene polymerized noticeably within $5 \mathrm{~min}$ at $25{ }^{\circ} \mathrm{C}$. At the end of $21 \mathrm{~h}$ a white, glass-like polymer was obtained which did not melt at $240{ }^{\circ} \mathrm{C}$. See, ref. $5 a$.

9 For non-polar mechanisms, see for example: (a) D. A. Singleton, B. E. Schulmeier, C. Hang, A. A. Thomas,
S.-W. Leung and S. R. Merrigan, Tetrahedron, 2001, 57, 5149-5160; (b) R. Jasiński, React. Kinet., Mech. Catal., 2016, 119, 49-57. For polar mechanisms, see for example: $(c)$ R. Jasiński, Monatsh. Chem., 2016, 147, 1207-1213; (d) R. Jasiński, J. Mol. Graphics Modell., 2017, 75, 55-61; (e) R. Jasiński, J. Fluorine Chem., 2018, 206, 1-7.

10 M. D. Barker, R. A. Dixon, S. Jones and B. J. Marsh, Tetrahedron, 2006, 62, 11663-11669.

11 E. Podyacheva, O. I. Afanasyev, A. A. Tsygankov, M. Makarova and D. Chusov, Synthesis, 2019, 51, 2667-2677 and references therein.

12 For reviews, see: (a) M. C. Willis, J. Chem. Soc., Perkin Trans. 1, 1999, 1765-1784; (b) X.-P. Zeng, Z.-Y. Cao, Y.-H. Wang, F. Zhou and J. Zhou, Chem. Rev., 2016, 116, 7330-7396; (c) T. Suzuki, Tetrahedron Lett., 2017, 58, 4731-4739.

13 M. Shimizu, Y. Nishigaki and A. Wakabayashi, Tetrahedron Lett., 1999, 40, 8873-8876.

14 M. Ostendorf, R. Romagnoli, I. C. Pereiro, E. C. Roos, M. J. Moolenaar, W. N. Speckamp and H. Hiemstra, Tetrahedron: Asymmetry, 1997, 8, 1773-1789.

15 (a) C. Ramarao, R. Nandipati, R. Navakoti and R. Kottamasu, Tetrahedron Lett., 2012, 53, 637-640; (b) D. E. A. Brittain, C. M. Griffiths-Jones, M. R. Linder, M. D. Smith, C. McCusker, J. S. Barlow, R. Akiyama, K. Yasuda and S. V. Ley, Angew. Chem., Int. Ed., 2005, 44, 2732-2737; (c) N. Mariet, H. Pellissier, M. Ibrahim-Ouali and M. Santelli, Eur. J. Org. Chem., 2004, 2679-2691.

16 (a) M. Shimizu, M. Kamei and T. Fujisawa, Tetrahedron Lett., 1995, 36, 8607-8610; (b) M. Shimizu, K. Tsukamoto and T. Fujisawa, Tetrahedron Lett., 1997, 38, 5193-5196; (c) M. Shimizu, K. Tsukamoto, T. Matsutani and T. Fujisawa, Tetrahedron, 1998, 54, 10265-10274. 